\title{
STRENGTHENING CANADIAN CITIZENSHIP: BUT HOW AND FOR WHOSE BENEFIT? THE RISE AND FALL OF (BILL) C24, OR TOWARDS A HIERARCHIZED CANADIAN CITIZENSHIP
}

\author{
by \\ Antoine Marie Zacharie Habumukiza \\ BA, National University of Rwanda, 2006 \\ MA, Queen's University, 2009 \\ Diploma (SSW), Seneca College, 2016
}

\begin{abstract}
A Major Research Paper
presented to Ryerson University

in partial fulfillment of the requirements for the degree of

\author{
Master of Arts \\ in the program of
}

Immigration and Settlement Studies
\end{abstract}

Toronto, Ontario, Canada, 2017

(C) Antoine Marie Zacharie Habumukiza 2017 


\section{AUTHOR'S DECLARATION FOR ELECTRONIC SUBMISSION OF A MAJOR RESEARCH PAPER (MRP)}

I hereby declare that I am the sole author of this Major Research Paper. This is a true copy of the MRP, including any required final revisions.

I authorize Ryerson University to lend this MRP to other institutions or individuals for the purpose of scholarly research

I further authorize Ryerson University to reproduce this MRP by photocopying or by other means, in total or in part, at the request of other institutions or individuals for the purpose of scholarly research.

I understand that my MRP may be made electronically available to the public.

Antoine Marie Zacharie Habumukiza 


\title{
STRENGTHENING CANADIAN CITIZENSHIP: BUT HOW AND FOR WHOSE BENEFIT? THE RISE AND FALL OF (BILL) C24, OR TOWARDS A HIERARCHIZED CANADIAN CITIZENSHIP
}

\author{
Antoine Marie Zacharie Habumukiza \\ Master of Arts, 2017 \\ Immigration and Settlement Studies \\ Ryerson University
}

\begin{abstract}
While Statistics Canada evidences immigration to be a key driver of Canada's population growth, unwelcoming immigration settlement policies and Canadian citizenship legislation combine to impede recent immigrants' integration. Above all, citizenship policy plays a pivotal role in easing newcomers' integration into the host polity by transforming them into citizens. Through naturalization, immigrants acquire legal citizenship; their substantive citizenship makes them enjoy rights and exercise responsibilities embedded in, and defined by citizenship policy. This paper argues that, by institutionalizing a conditional citizenship for new immigrants, recent changes to the Canadian citizenship regime brought by C-24 in June 2014 then repealed by C- 6 in June 2017, not only weaken but jeopardize both legal and substantive citizenship of dual Canadian citizens and, consequently, hinder their successful integration into the Canadian polity. This study concludes that the lived experiences of recent immigrants mark a distinction between new Canadians'/visible minorities' alientity and mainstream Canadian identity.
\end{abstract}

Key words: (Bill) C-24; (Bill) C-6; Canadian citizenship regime change; Recent immigrants' integration; New Canadians' alientity 


\section{Acknowledgments}

Dr. Myer Siemiatycki, accept this as a token of my gratitude not only for having agreed to accompany me throughout the drafting of this work but especially for having always been there for me even when I wasn't available.

I am also grateful to you, Dr. Harald Bauder: you would probably agree with me that you've actively participated in the maturation of my thought as it is developed in this MRP, which you very willingly accepted to criticize as second reader.

The fact that I was a full-time student and a full-time employee as well, I needed accommodation which I got from both my workplace's supervisors at Le Centre francophone de Toronto / The Francophone Centre of Toronto (CFT), and my professors at Ryerson University. Thus,

- To Aline Hélène Merlette, my former supervisor and Coordinator of Orientation Program, Newcomer Services Department at the CFT: I am extremely grateful to you not only for your open-mindedness but for your sense of humanity; I would not have even finished my courses within one year without your accommodation. Please, count my completion of this program of study among your Orientation Program's Bons Coups.

- To Oureye Seck, my worksite placement supervisor and Coordinator of Community Connections Program, Newcomer Services Department at the CFT: Your bold assiduity in your everyday tasks, your sense of responsibility and your natural sense of humor, have always raised my spirits, especially when I had to work at your side either in the evening or during the week-end, after an exhausting or emotionally stressful long day or week.

- To Dr. Doreen Fumia, my single day class's professor at Ryerson: as I mentioned to you before, I really appreciated the way you've been supportive towards me; allow me to repeat what I promised you: I will accommodate others in memory of you.

There is a saying that every cloud has a silver lining. It is very true. When I was robbed of my laptop at Ryerson's library only a few days before the end of August 2017, Fortune offered me to meet a good Samaritan. Venu Gudivada, a librarian at Ryerson, who afterwards presented himself to me as the father of one of my fellow-students, kindly lent me his laptop. May he find here the expression on my sincere thanks and the testimony of my deepest gratitude.

Last but not least, I am a husband and a father of three. To Marie Claire my wife, and to Mugire Fidèle, Hirwa-Auguste and Ineza-Richard my boys: I acknowledge that you were obliged to endure my year-long absence at Ryerson University, a year that unfortunately was in addition to other years of absence spent at Seneca College, Western University and Queen's University. Unfortunately for you the storm is not yet completely over. For I still need the current academic year (2017-18) to finish my PhD Dissertation at Western. After that, I promise, the storm will be over. Inshallah. 


\section{Contents}

Author's Declaration ......................................................................................................... ii

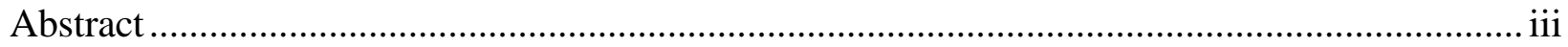

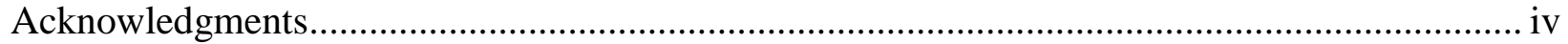

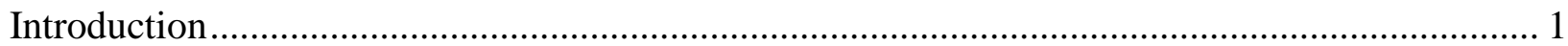

Chap.1. Conceptual and Theoretical Framework ................................................................ 7

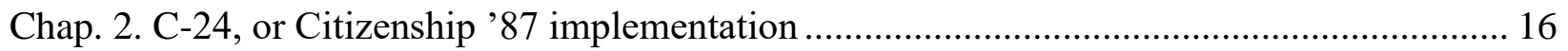

Chap.3. C-6: The fall of C-24 and the Return to the 1977 Canadian Citizenship Regime.......... 28

Conclusion: Canadian citizenship and New Canadians' Alientity .......................................... 34

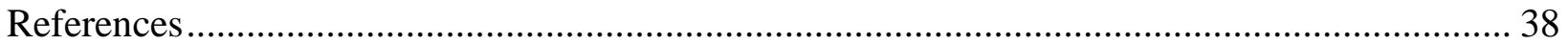




\section{Introduction}

Both the history of Canada as a settler society and reports from Statistics Canada affirm that immigration has always been and will likely continue to be a key driver of Canada's population growth. To be accurate, statistics and projections from the 2011 Population Census show that "starting in 2031, migratory increase could account for more than $80 \%$ of Canada's population growth, compared to about 67\%" in 2011 (Statistics Canada, 2012: 4). Furthermore, Statistics Canada warns that "Without a sustained level of immigration or a substantial increase in fertility, Canada's population growth could, within 20 years, be close to zero" (Ibid.). That Canada relies on immigrants for its demographic and economic growth, it is an undeniable fact that has earned it the name of "a country of immigrants" (Kelly \& Trebilcock, 2013: 4).

However, bringing immigrants to Canada is one thing and integrating them into the Canadian society is another thing. As Siemiatycki notes, "Integration addresses the role and place of immigrants in the new country they have moved to" (2015: 93); in that sense, integration amounts to "the ability to contribute, free of barriers, to every dimension of [host society] life, that is, economic, social, cultural and political" (Shields et al., 2016: 5). Defined in this way, the integration is not achieved overnight: it "is a long process, even an inter-generational process" (Biles, 2008:174).

While bringing immigrants to Canada and easing their integration process in the destination community should be going hand in hand, the history of Canadian immigration policy coupled with unwelcoming immigration settlement policies as well as the evolution of the relatively young Canadian citizenship legislation, reveal that integration of immigrants in the Canadian community remains not only an undermined but a challenging field. For the purposes of this study, I will set aside Canadian immigration and settlement policies and focus on citizenship legislation. 
Specifically, I will emphasize the recent changes to the 1977 Canadian Citizenship Act pertaining not only to the definition of Canadian citizenship but also to the place reserved to dual and potential dual Canadian citizen - and to recent immigrants as well - in the Canadian polity. In this study, I argue that changes that were brought by $\mathrm{C}-24$ to the Canadian citizenship regime then repealed by C- $6^{1}$ - changes that flouted both the 1971 Canadian Multiculturalism Policy and the Canadian Charter of Rights and Freedoms -, not only weaken but especially jeopardize both legal and substantive citizenship of dual Canadian citizens by institutionalizing a conditional citizenship for them and, consequently, hinder their successful integration into the Canadian polity. In this analysis, I agree with Bloemraad who highlights the intertwined relations between successful integration and citizenship legislation as follows: "Any long-term strategy for successful immigrant integration must put citizenship policy front and center" (2007: 57). She adds that "since citizenship remains the primary way of accessing the rights and benefits that government provides, citizenship policy is of central importance to immigrants" (2007: 58).

Discoursing on hardships embedded in the process of migrating and integrating to, and of qualifying to become a full citizen of, Canada, as well as questioning the genuineness of the membership of immigrants in the Canadian social fabric, however, are not a recent phenomenon. On the contrary, it is a very old phenomenon which cannot be considered as originating or resulting from "the new politics of immigration" that might have been recently developed by former settler societies as one could erroneously read it in The New Politics of Immigration and the End of Settler

\footnotetext{
${ }^{1}$ To those who might wonder why to focus on a bill that has been repealed, I would answer by quoting Edward Said's wisdom on reasons behind "Appeals to the past". He states that: "Appeals to the past are among the commonest of strategies in the interpretations of the present. What animates such appeals is not only disagreement about what happened in the past and what the past was, but uncertainty about whether the past really is past, over and concluded, or whether it continues, albeit in different forms, perhaps. This problem animates all sorts of discussions - about influence, about blame and judgement, about present actualities and future priorities" (Said, 1993: 3. I highlight). My point is that what animated Bill C-24, what made it a law didn't disappear because of Bill C-6 enactment; it is still there instead. Moreover, as we will see below, citizenship is defined by "who governs" (Ciprut, 2008:10).
} 
Societies, a book written by Catherine Dauvergne (2016). As a matter of fact, Valerie Knowles opens her Strangers at our Gates (2015) with remarks of William Scott, the former "superintendent of immigration from 1903 to 1924", on the high importance attached to, as well as on how hard is, becoming a genuine and full member of the Canadian social fabric: "More important than the drilling of armies, more important than the construction of navies, more important than the fiscal policy of this country is who shall come to Canada and be part and parcel of the Canadian people" (9). Similarly, Kelly \& Trebilcock, in their leading book on Canadian Immigration History consider that topic as a banal one as they write that it is "trite to predict that immigration issues will be at the heart of future debates about what it means to be a Canadian and to be a member of the Canadian community" (2013:4). It is in this perspective that recent changes to the Canadian citizenship policy make the question of whether recent immigrants can become full Canadian citizens - "with equal rights and duties" (Özdemir, 2007: 13) as "old-stock Canadians"2 (Gollom 2015) - gains momentum and becomes of paramount importance.

Indeed, it is quite clear that treating recent naturalized and (potential) dual Canadian citizens as permanent outsiders or better as inferior citizens is an issue that not only extends throughout the whole history of Canadian immigration but also and especially structures the essence of Canada - paradoxically - as a settler society. And as we know, there is no status that gives more rights and privileges than being a citizen of a Westphalian or modern nation-state, whether citizenship is acquired by birth or by choice through naturalization: both ways are governed and regulated by citizenship policy. An idea well expressed by Macklin - although she

\footnotetext{
${ }^{2}$ Defending the fact that the Conservative government had denied health-care benefits to convention refugees during the federal election campaign - that was three months after Bill C-24 was fully enacted -, Stephen Harper, then-Prime Minister of Canada, seized the opportunity to reveal how Canadians were categorized. He said: "I think that's something that both new and existing and old-stock Canadians can agree with" (Italics are mine). See: Mark Gollom. "Stephen Harper's 'old-stock Canadians': Politics of division or simple slip?" CBC News. Last Updated: Sep 19, 2015. Retrieved from: http://www.cbc.ca/news/politics/old-stock-canadians-stephen-harper-identity-politics-1.3234386
} 
adds up a significant nuance that will occupy us later - when she says that "Citizenship is the highest and more secure legal status one can hold in a state, but it is not inviolate" (2014: 4). The stakes are high, especially since many studies have shown that the more stable the status of immigrants is the more they have access to "rights and entitlements" (Austin \& Bauder, 2012: 21) that help them throughout their settlement and integration process. Hence the importance we attach to the Canadian citizenship legislation, as well as to recent changes that legislation has undergone.

In fact, while the first Canadian Citizenship Act dates from 1947, the second Citizenship Act was enacted three decades later in 1977. The third Citizenship Act that came into force on June 19, 2014, i. e. 37 years after the second, was repealed on June 19, 2017 exactly three years after its enactment. We may recall that the 2014 Conservative Citizenship Act and the 2017 Liberal Citizenship Act resulted from, respectively, Bill C-24, the Strengthening Canadian Citizenship Act and Bill C-6, an Act to amend the Citizenship Act and make consequential amendments to another Act. It is these very close-knit changes that inform or inspire the title of this study: "Strengthening and enhancing Canadian Citizenship: but how and for whose benefit?"

In this study, I intend to focus on C-24 to determine its origins, rise and fall, with the goal of analyzing what its promulgation, repeal and replacement by C-6 mean to immigrants to Canada for whom acquiring Canadian citizenship through naturalization is a crucial step in their process of social and political integration in Canada. Anderson and Black argue that "Naturalization formally incorporates non-citizens into the national political community by recognizing in them certain political rights and responsibilities. The acquisition of legal citizenship status is therefore a fundamental feature of political integration that can influence the course that it takes" (2008: 49).

Nevertheless, acquiring legal citizenship alone is not enough to ensure adequate integration immigrants need; it must be accompanied by substantive citizenship. Macklin remarks that the 
former refers to "the juridical status of membership held by an individual in relation to a territorial nation-state", and the latter to "the rights, entitlements, obligations, duties, and other legal, social, and political practices that constitute the individual as an active, participatory, and functional political subject within a nation-state" (2006: 22-23). As Macklin explains, the legal citizenship “does not necessarily embody a 'thick' relationship between individual and the state. Instead, it simply denotes a legal status entitling the holders to certain rights denied to non-citizens" (2006: 23).

This study will be limited to literature review on citizenship concept and Canadian citizenship policy analysis. Precisely, before the examination of a conditional citizenship that was explicitly established by C- 24 then invalidated by C- 6 as mentioned above, a literature review of theories of citizenship will emphasize on the one hand the fact that despite its universal use, citizenship in its essence is a malleable concept whereas in practice it is entirely at the mercy of those in power (Ciprut, 2008: 10) in every nation-state; on the other hand, an emphasis will be put on the "idea of citizenship as an exclusionary practice" (Isin and Wood, 1999: 55) in addition to being a hierarchized institution. This chapter will also talk about what can be called the flip side of naturalization, in order to underline the fact that, most of the cases, the latter doesn't really bring to naturalized citizens full citizenship status that would allow them automatic access into the community of value of their new polity.

Then I will analyze the rise and fall of (Bill) C-24. I will argue that while the 1977 Canadian Citizenship Act had made significate changes to guarantee both legal and substantive citizenships to both Canadians by birth and naturalized Canadians by making Canadian citizenship a right rather than a privilege as it was before, the 2014 Conservative Citizenship Act, by redesigning the Canadian citizenship through the implementation of the 1987 Conservative's white paper called 
Citizenship '87: Proud to be Canadian, has not only reversed that definition but institutionalized a second-class of citizens made of dual Canadians citizens. Under the new citizenship regime Canadian citizenship for the latter became not only conditional but more importantly volatile.

Given that the fall of C-24 coincides with the enactment of Bill C-6, I will examine the latter by re-placing it in its context of emergence which will allow me to focus on the "links between politics, ideology, and citizenship" (Ciprut, 2008: 10) in the Canadian context ${ }^{3}$. Indeed, C-6 echoed the Liberal Party slogan "a Canadian is a Canadian is a Canadian", characteristic of, and likely, one of the main takeaways from, Liberals' federal election campaign of 2015. Such a slogan contrasts with then-Prime Minister Stephen Harper's "new and existing and old-stock Canadians" expression used to convey politically what C-24 conveyed legally: the stratification of various components or groups of the Canadian population. Such a stratification is far from being innocent, since it is verbalized during the federal election campaign. In this section, my intention will also be to analyze C-6 as a return to the core spirit of the 1977 Citizenship Act, namely an improved access to citizenship for qualified applicants as well as an equal treatment of all Canadians without exceptions (Canada 1987).

A conclusion of this study will be an opportunity to question but also "name" a continuous practice of Canada's ruling-class of considering recent immigrants as foreign bodies that will remain as such forever, even after they have acquired Canadian citizenship. Such a state of "alienhood" (Marciniak 2006) which can also be designated by the Lamizet's neologism of "alientity" (Lamizet 2014 \& 2015) makes those recent Canadians look like and be treated as permanent "outsiders" by the host community.

\footnotetext{
${ }^{3}$ Given the scope and the breadth of this topic, scientific humility obliges me to specify that I cannot fully exploit it in these few pages of this MRP. Perhaps I could work on that subject in my subsequent studies.
} 


\section{Chap.1. Conceptual and Theoretical Framework}

In this research, the conceptual and theoretical framework draws upon theories of citizenship. As citizenship theorists point out, however, there is no single definition of their subject of study; likewise, definitions of citizenship are as varied as theories of citizenship are (Dahlstedt et al., 2015; Janoski 1998). The fact that there is neither a unique nor universal definition of citizenship, makes it even harder to grasp its whole meaning as well as what goes with or without it. Some definitions of citizenship evoke its ever-changing character while others emphasize the intermittent absence of the notion of equality as what constitutes the core of the citizenship.

In one way or another, however, different conceptualizations and theories of citizenship "concern the question of [political] identity, civic allegiance, and membership" (Bekemans, 2014: 25 ) in a specific sovereign state or political community. As for the definitions of citizenship, they focus on how and under which conditions citizens enjoy citizenship. For example, Ciprut defines citizenship as "a bundle of rights and obligations that define a person's societal role" (2008: 17) while Ray defines it as "a bundle of entitlements and obligations, which constitute individuals as full-fledged members of a social - political community, providing them with access to scarce resources" (2007: 2). As for Cairns, "citizenship is a linking mechanism, which in its most perfect expression binds the citizenry to the state and to each other and reinforces empathy and sustains solidarity... by defining who is 'one of us"' (Cairns, 1999: 4).

It is worth noting that even in the same polity not everyone benefits from citizenship in the same way; a fact that is due to a double inequality embedded in citizenship both as a concept and as a practice. As such, to paraphrase C. G. Anderson (2008: 82), citizenship distinguishes citizens from non-citizens, id est insiders from outsiders on the one hand; on the other hand, unfortunately, citizenship in practice does also differentiate among insiders more deserving citizens from less 
deserving ones. In other words, this is since the happy few that remodel citizenship as they wish also would not only designate those who are likely to become full members within their polity but also invent criteria or put forward ready-made reasons to favor some of those who enjoy the same status as citizens. As a turn away from liberal ideas, such a practice is not without recalling the famous sentence of George Orwell on the equality of animals in The Animal Farm: "All animals are equal, but some animals are more equal than others." A practice that more importantly refers to the exclusionary nature of citizenship since its original creation in ancient Greece first and then in the Roman Empire.

Speaking of how literature on theories of citizenship is approached even if so diverse, Willem Maas notes that it "may be grouped into two strands captured under the terms republican (occasionally conflated with communitarian) and liberal" (2013:5). On the republican concept of citizenship, Maas explains that it "emphasizes participation and civic self-rule, as in Aristotle's view of citizenship meaning not only being ruled but also sharing in the ruling, Machiavelli's description of Italian city-states, and Rousseau's focus on determining the collective will" (2013: 5). Liberal citizenship, by contrast, Maas keeps explaining, "emphasizes the rule of law and the individual's liberty from state interference, a status than an activity" (Ibid.).

As a critique of the liberal tradition of citizenship, Heater observes that liberal citizenship "involves a loosely committed relationship to the state, a relationship held in place in the main by a set of civic rights, honoured by the state, which otherwise interferes as little as possible in the citizen's life" (1999: 4). In contrast to liberals' emphasis on rights, remarks Richard Bellamy (2000), "republicans underline the role of duties and active participation as the constitutive elements of citizenship. In fact, they reverse the relation between rights and politics as it is 
understood in liberalism. Rights are regarded as the products of the political process by republicans, rather than its presuppositions" (cited in Bekemans, 2014: 26-27).

Nevertheless, whether it is republican or liberal, citizenship as both a concept and a practice, is always "a political construction" (Maas, 2013: 3). Through that construction, governments and ruling-classes define civil, political and social rights of citizens living under their authorities, as those rights appear in Thomas Humphrey Marshal's (1950) famous definition of modern citizenship. According to Marshal,

Citizenship is a status bestowed on those who are full members of community. All who possess the status are equal with respect to the rights and duties with which the status is endowed. There is no universal principle that determines what those rights and duties shall be, but societies in which citizenship is a developing institution create an image of an ideal citizenship against which achievement can be measured and towards which aspiration can be directed. The urge forward along the path thus plotted is an urge towards a fuller measure of equality, an enrichment of the stuff of which the status is made and an increase in the number of those on whom the status is bestowed. (1950: 28-29. Italics are mine.)

Therefore, citizenship is a social institution. As such, citizenship is neither a readymade concept nor a "finished product" that is here at the Planet Earth, available equally to individual nation-states, and ready for them and for their people to use. The fact that citizenship is a social and political construction makes it as malleable as some industrial raw materials whose final form depends on the will of different designers. Now the question is to know who has the power not only to define, shape and reshape citizenship but also to determine and review - as it pleases who are suitable citizens. This is partly because, as Isin and Wood point out, in western countries “every age since the ancient Greeks has fashioned a new image of the citizen" (1999: 156). Such 
a practice or a process is still going on especially in this era characterized by globalization and the intense migratory phenomenon.

Part of the answer to the above-mentioned question can be found indirectly in the first sentence of Marshall's citizenship definition, namely "Citizenship is a status bestowed on those who are full members of community" (1950: 28). A sentence whose meaning implies that there is an institution invested with power to bestow citizenship to those who qualify. Another part of the above question is embedded in the so-called "contract" between citizens and the state, as it is described in "Rights, Obligations and Changing Citizenship ideals", an article by Dahlstedt et al.; more importantly, the authors describe the nature of such a contract and how it really works:

Thus the contract between the individual and the state that gives citizenship its content does not last forever but is constantly rewritten, especially as a result of conflicts between different interests $[\ldots]$. How is the contract written? What does the contract look like and how does it change? The question of membership in the community of citizenship, who are included and who are not, is anything but uncomplicated. There are always a few who write the contract, not everybody is included and those who are do not necessarily all enjoy the same conditions. $(2015: 90)$

The power to shape citizenship - and, therefore, to decide who can belong to the polity and who cannot - is invested with a small group among those who are in power; their actions pertaining to citizenship remodulations depend solely to what they consider to be priorities in their own agendas set up in a specific context.

Speaking of those priorities, Ray emphasize the security of the dominant group which has become more and more the main reason of redefining citizenship and of restricting outsiders from 
acquiring citizenship. According to Ray, "Modern citizenship has developed not only as a consequence of popular democratic pressures, but also in response to the ruling-class's requirements for security, a factor ignored by many theorists of citizenship" (2007: v). Ray's point of view on motivations of ruling-class's ever-changing plans to manipulate both formal and substantive aspects of citizenship, agrees with Ciprut's remarks on how citizenship is handled by those who hold the power. As Ciprut puts it,

The mentalities that color the political environments in which democratic citizenship is exercised also determine its functions, its limits, and its latitudes, usually by imparting to a society's agenda its content, its priorities, and its new direction. Thus, practices and patterns of citizenship can vary according to 'who governs'. (2008: 10)

Thus, the "Band of brothers" - to borrow from William Shakespeare's St Crispin's Day Speech - made of those who really govern, is the one that coins citizenship meaning, establishes ways by/in which people will have access to it, and then guarantees it to the "happy few" (Ibid.) who qualify. But clearly citizenship is not given to whoever wants to be a citizen: "According to present-day conceptions, citizenship is a form of membership in a polity and attaches to particular persons" (Ciprut, 2008: 21). Even to those "particular persons", it attaches to them in different ways, which leads to the creation of what Mulhern calls "grades of citizenship" as it appears through Mulhern's analysis of the political economy of citizenship in the USA - an analysis that is also valid in Canada, subject to certain exceptions: "Vestiges of grades of citizenship survive in the United States today, perhaps more in some places than others. Birth officially trumps naturalization in the United States, and age also plays a part. So do residence and fulfillment of administrative requirements. Wealth and indigence do not. U.S. citizenship does not have a means test." (2008: 31) 
Even when we think of the best definition of citizenship, it is not only tinged with inequalities embedded in what is called "shifting set of statuses" (Armstrong, 2006:148) but also fails to intertwine citizenship and equality, as it is the case in the following "best available definition" that Christopher G. Armstrong (2006) gives of citizenship:

On the best available definition, the notion of citizenship refers to two things. The first relates citizenship to that set of practices and institutions which define individuals as equal members of a polity, which apprehend a person as a competent member of society, 'and which as a consequence shape the flow of resources to persons and social groups' [...]. And, secondly, citizenship is the result(s) of those practices. Namely, it is a status, or, more precisely, a complex and sometimes shifting set of statuses [...], which determines both a set of rights and responsibilities, and the relation of individuals to governing powers and each other. The reason why equality and citizenship are so often complicated concepts [...] is that, in modern West, debates about the meaning of citizenship as a status of equal members have been a key place where demands of equality have been collected and interrelated. (148-149)

Debating Canadian citizenship and equality of Canadian citizens might seem to be a continuation of this debate on concepts of citizenship and equality in general. In any case, facts detailed above prove that it is up to the ruling-class of any sovereign state to define citizenship and determine individuals that can, and to what extent they can enjoy rights citizenship brings with it. In the Canadian context, where "the enduring Britishness of Canada" (Anderson, 2011: 208) plays a key-role in defining Canadian values and national identity for the majority and dominant class,

\footnotetext{
4 "The importance of appreciating the enduring Britishness of Canada is the focus of C. P. Champion's The Strange Demise of British Canada. '[T] he British tradition is not something foreign', he insists, 'it is a constitutive part of Canadian identity"' (Anderson, 2011: 208).
} 
Mulhern's grades of citizenship as well as Armstrong's shifting set of statuses are perceived in the lived reality of visible minorities where their Canadian citizenship differs from old-stock Canadians' citizenship.

Such a double standard that applies to Canadian citizens depending on their different grades of citizenship and statuses, confirms the exclusionary nature that is the cornerstone of any citizenship and might seem normal. However, the multicultural essence of Canadian society should be reflected in Canadian citizenship, more in facts than in speech. "For some time now, concerns have been raised that Canadians — and more particularly, new Canadians - are losing or have lost sight of the values that give meaning to being Canadian (Anderson, 2008: 207), especially in the aftermath of recent changes to the Canadian citizenship Act.

In fact, under the 2014 Conservative Citizenship Act, Canadian citizenship became exactly "a mechanism of distinction between migrants and non-migrants based on association with place, origin, and national community" (Bauder, 2008: 319). The double inequality referred to above comes back to the surface and appears to be the most appropriate concept for defining the current state of Canadian citizenship resulting from its recent re-definition under (Bill) C-24, the Strengthening Canadian Citizenship Act. Indeed, under C-24, Canadian citizenship does "not simply distinguish those who possess it from those who do not, however, but [consists] of different categories, an idea captured by the terms 'first-class' and 'second-class' citizenship" (Anderson, 2008: 82). More specifically, under C-24, Canadian citizenship is no longer a multicultural citizenship which was "based on the bedrock principles of equality, diversity, and community" (Canada, 1987: 1), principles that were reflected in the 1977 Canadian Citizenship Act; rather, it became a hierarchized citizenship since it favors white majority that has it as an inalienable right, and hinders visible and racialized minorities that have it as a privilege. 
Before we conclude this chapter on conceptualization and theories of citizenship, let's look at what one can call the flip side of naturalization as well as at the fact that it is hard for naturalized citizens to have access into what Anderson calls a "community of value" (2013: 93). As I mentioned earlier, the focus in this study will be on Canadian citizenship legislation and changes it has undergone recently, which made Canadian citizenship fragile especially for naturalized Canadians. Speaking of naturalization and how and to what extent it makes strangers of yesterday citizens of today, Bridget Anderson (2013) raises also the question of incompleteness of the work done by naturalization. An incompleteness that would mean that naturalization has both merits and mirages, where the latter constitute the flip side of naturalization. "Naturalization procedures", Anderson notes, "serve an important symbolic function both in delineating the boundaries of the national community, and in asserting that national community as a community of value" (2013: 93). "By incorporating non-citizens into any given polity", says the author, "naturalization reveals the permeability of the boundary between 'us' and 'them"' (Ibid.). But to what extent? The answer can be found in Anderson's following excerpt: "However, this inclusion is contingent, and formal citizenship does not neatly map on to membership in the community of value. In this way, naturalization also reveals the impermeability of the boundary between us and them, and the contingency of citizenship" (2013: 93).

The concept of community of value, as it is defined by Bridget Anderson, seems to be reminiscent of the language-people-nation relationship. An idea Anderson's following statement seems to confirm: "The community of value is one of the ways states claim legitimacy, and in this way, it often overlaps with ideas of the nation" (2013: 3). She goes on specifying that "modern states portray themselves not as arbitrary collections of people hung together by a common legal status but as a community of value composed of people who share common ideals and (exemplary) 
patterns of behaviour expressed through ethnicity, religion, culture, or language - that is its members have shared values. They partake in certain forms of social relations, in "communities"' (2013:2). Thus, for immigrants, being naturalized citizen - i. e. acquiring legal citizenship doesn't mean securing one's place in the community of value. More importantly, the community of value must be protected from the external invader. Bridget Anderson notes: "As well as manifesting values, the community of value is valued. In this sense, it needs protection, and increasingly it seems it needs protection from outsiders. At the national level, outsiders are equited with foreigners" (2013: 3).

The representative figure of the foreigner, in the present case which concerns us, is that of an immigrant. Thus, for non-citizens, naturalization unlikely leads to full and neutral citizenship. On the contrary, it leads to a citizenship gorged with flaws and exposed to all kinds of erosion. Even worse, it does not totally abolish strangeness of citizens by choice, especially when the latter are referred to as racialized or visible minorities. Hence naturalized citizens do not always escape being designated as aliens, in one way or another. 


\section{Chap. 2. C-24, or Citizenship' 87 implementation}

On February $6^{\text {th }}$, 2014, a well-decried Bill C-24, the Strengthening Canadian Citizenship Act was introduced in the House of Commons by then-Minister of Citizenship and Immigration Chris Alexander. On June $19^{\text {th }}, 2014$, i. e. approximately four months later only, Bill C-24 received the royal assent and became a law. Scholars, lawyers, advocates for Immigrant and Refugee Rights and media among others, wrote extensively but vainly against the enactment of this (Bill) C-24, which would redefine Canadian Citizenship acquired by recent naturalized dual citizens as a revocable privilege, and therefore institutionalize second-class citizens in Canada. However, what those who have expressed their opposition to the 2014 Conservative Citizenship Act did not emphasize is the close connection between (Bill) C-24 and Citizenship '87: Proud to be Canadian. In this section, I intent to revisit C-24 and read it as an outright implementation of Citizenship '87, a white paper published in June 1987 by the Conservative government of that time; this document contained the then-Government proposals to amend the 1977 Citizenship Act, which are reflected in what was its objective, namely: "To give more depth and meaning to Canadian citizenship." (Canada, 1987: 3). It should be noted that "the Strengthening Canadian citizenship" of Bill C-24 semantically does not differ in any way from the objective mentioned above. Thus, I argue that by implementing Citizenship '87, whose intent was to amend the 1977 Citizenship Act and reinstate some of the provisions that were embedded in the 1947 first Canadian citizenship Act, the thenConservative Government meant to establish a new citizenship regime that turns away from Canadian diversity and multiculturalism, and segregates recent Canadians and immigrants from old-stock Canadians. The new citizenship regime was tied to the "Canadian heritage" that ignores the contribution of innumerable immigrants and considers only what seems to link Canada to its British roots. 
Indeed, the ultimate goal of both (Bill) C-24, the Strengthening Canadian Citizenship and the 1987 white paper Citizenship '87: Proud to be Canadian was to redesign the Canadian citizenship regime. Drawing upon Marshall's notion of citizenship as a social construction that changes through time, Jane Jenson and Susan D. Phillips argue that "the concept of citizenship regime denotes the institutional arrangements, rules, and understandings that guide and shape concurrent policy decisions and expenditures of states, problem definitions by states and citizens, and claims-making by citizens" (2001: 72). More precisely, Jenson and Phillips go on explaining that "a citizenship regime encodes within it a paradigmatic representation of identities, of the 'national' as well as the 'model citizen', the 'second-class citizen', and the non-citizen. It also encodes representations of the proper and legitimate social relations among and within these categories, as well as the borders of 'public' and 'private' (Ibid.). Thus, depending on the citizenship regime in place, citizenship would function as a diamond ring used not only to connect citizens (intimately, solidly or loosely) to their state, and the state to its citizens, but also to intertwin citizens among themselves.

In their analysis of citizenship regime, Jane Jenson and Martin Papillon argue that the latter has four dimensions that I can summarize as follows:

1. On the one hand, citizenship establishes the boundaries of inclusion and exclusion of a political community through formal recognition of particular rights and access to mechanisms for the exercise of those rights; on the other hand, it identifies those entitled to full citizenship status and those who only hold second class status;

2. Citizenship regime prescribes the democratic rules of the game for a polity. Included in those rules are the institutional mechanisms giving access to the state, the modes of participation in civic life and public debates and the legitimacy of specific forms of claims making; 
3. By recognizing the formal status to individuals as well as using cultural and historical references to qualify the community, a citizenship regime contributes also to the definition of nation, in both the narrow passport-holding sense of nationality and the more complicated notion of national identity;

4. Lastly, citizenship regime, by defining the rules and practice of membership, sets the geographical borders of the political community, giving meaning to the frontiers between states. (2000: 246)

In fact, the Citizenship Act matters because it designates who belongs to the nation-state and who doesn't; distinguishes who deserves support and protection by the state from who doesn't; specifies both who is a full member of Canadian polity and who is denizen. So, changing Canadian citizenship regime which means changing rules of interactions and interrelations between individuals, families, communities, ethnic groups on the one hand, and the state on the other hand, is a political practice which is not only heavy on importance but also accompanied by serious consequences; especially when this political action is carried out while interests of certain members of the same political community are completely ignored, which was the case when Bill C-24 was enacted.

Concerned about how to thwart immigrants who come to Canada simply for obtaining "a passport of convenience" (Alexander, 2014) and whose loyalty to Canada is nil, on June 19, 2014 the Conservative government introduced major changes to the 1977 Citizenship Act by enacting Bill C-24, the Strengthening Canadian Citizenship Act. According to Jason Kenny, the former Minister of Citizenship and Immigration, one of the Bill C-24 main purposes was to make Canadian Citizenship "harder to get and easier to lose" (cited in Knowles, 2016: 279). As the following comparison of C-24/Citizenship '87 and the 1977 Act proves, the key-driving of the 
former contrasts with the thrust of the letter which is "improved access" to citizenship and "equal treatment" of all Canadians.

Citizenship'87, the 1987 Conservative's white paper provides the best summary of the 1977 Citizenship Act and of the spirit behind it as follows:

The general thrust of the new Act could be summarized in five words: improved access and equal treatment. It sought to promote citizenship among newcomers by removing or lowering barriers. It reduced the residence requirement for would-be citizens from five years to three. It eliminated controls on plural citizenship. It also placed heightened emphasis on the equal treatment of men and women, removed all special treatment of British nationals, and guaranteed that individual applicants for Canadian citizenship would receive equal treatment. (Canada, 1987: 8)

More importantly, Citizenship ' 87 goes on stating that "the 1977 Act declared citizenship for all qualified applicants to be a right, rather than a privilege. Finally, it reaffirmed that Canadian citizens by birth and citizens by choice have identical rights and responsibilities" (Ibid.).

According to Citizenship ' 87 once again, "From the beginning, the idea of having a Citizenship Act was to give equal citizenship status to Canadians by birth and Canadians by choice, to extend Canadian citizenship to as many qualified people as possible, to impress upon all Canadians the value of citizenship status, and to promote national unity" (Citizenship '87: 6). It can be said without a reservation that the 1977 Act agrees with the above-mentioned ideal, whereas Citizenship '87 turns away from it. 
The 1987 white paper's objective was to draft "a new Citizenship Act", i.e. to change the Canadian Citizenship regime to precisely "give more depth and meaning to Canadian citizenship" (Canada, 1987: 3). Overall, it criticizes and was against the "overriding fairness" (Canada, 1987: 14) that was embedded in the 1977 Act; it reads: "a hallmark of the 1977 Act was its overriding fairness. It sought to extend equal treatment to all in citizenship matters, with special emphasis on equal treatment of both sexes" (Canada, 1987: 14).

To achieve its main objective mentioned above, the 1987 white paper undoes the entire 1977 Act item by item. The first item it undoes pertains to plural citizenship where recommendations are made to limit the number of dual Canadian citizens referred to as “'international' Canadian citizen" (Canada, 1987:10) by simply reinstating the "version of the earlier practice" (Ibid.) that makes dual citizenship unacceptable to both native-born and naturalized Canadians.

Furthermore, Citiznship' 87 recommended that Canadian citizenship should become again a privilege. To enhance the value of this "privilege", the white paper suggests to "extend the length of time immigrant must spend in the country before qualifying" and stipulates that "residence [which means physical presence in Canada] be calculated only from the time an applicant for citizenship has been lawfully admitted as a landed immigrant" (Canada,1987: 11).

The 1987 white paper recommended also "blocking citizenship acquisition" as well as citizenship revocation for crime committed outside of Canada with the intent "to protect the integrity of Canadian citizenship against abuse by international criminal or terrorists" (Canada, 1987: 13). 
What emerges from the 1987 white paper proposed change of the regime of Canadian citizenship could be interpreted as follows: Canadians by birth with no other citizenship are the only true Canadians: they are more equal than any other Canadians; therefore, all Canadians do not deserve an equal treatment.

Before Bill C-24 was enacted, it is worth to mention that five bills whose common goal was to change the 1977 Act, didn't receive the royal assent ${ }^{5}$. First of all, in 1993, the Liberal government "announced its intention to overhaul the Act, and asked the Standing Committee on Citizenship and Immigration to provide its advice. This appeared in the report Canadian Citizenship: A Sense of Belonging, which was presented to the House of Commons in June 1994; however, no bill was forthcoming in the 35th Parliament" (Young 1997: 2). Other bills are, chronologically, Bill C-63 which was introduced on 7 December 1998, Bill C-16 introduced on 25 November 1999, Bill C-18 introduced on 31 October 2002, Bill S-36 which was introduced in 2001 by senator Noel A. Kinsella, and Bill C-271 introduced by former Liberal MP Andrew Telegdi on 29 October 2002 (Garcea, 2006: 205-210). However, there had been two other bills that have made amendments to the Citizenship Act, 1977. In 2007, to begin, Bill C-14, An Act to amend the Citizenship Act (adoption), came into force and was intended to grant Canadian citizenship to children adopted abroad. A year after, Bill C-37, An Act to amend the Citizenship Act was enacted, and was intended a) to passing on the Canadian citizenship by descent to the first generation of children born or adopted abroad, and b) to granting Canadian citizenship to "Lost Canadians"; it came into force in April 2009.

\footnotetext{
${ }^{5}$ In May 2012, the Conservative Member of Parliament Devinder Shory proposed Bill C-425, an Act to amend the Citizenship Act (honouring the Canadian Armed Forces). It is said that Bill C-24 follows closely that bill on stipulations governing revocation of citizenship and "fast-tracking of citizenship acquisition for members of the Canadian Armed forces" (Winter, 2015: 27).
} 
Commenting on Bill C-63, Bill C-16, Bill C-18, Bill S-36 and Bill C-271 developed under the former prime minister Jean Chrétien and his successor Paul Martin, Joseph Garcea notes that their purpose included, among others: "enhancing the integrity of the citizenship system by improving policies and procedures for granting, refusing, revoking, and annulling citizenship to enhance protections against potential abuses both by those who treated it as a 'citizenship of convenience' for personal economic benefits and those who posed a threat either to personal or national security" (2006:205). Moreover, Garcea mentions that "the overarching goals of the reform initiatives undertaken by successive governments were both to improve the naturalization and denaturalization processes and to foster Canadian identity, unity, and security in light of changing Canadian conceptions of citizenship, and the changing realities of international security" (2006: 221).

The author goes on writing that at the time when the above-mentioned five bills failed to become laws (i. e. from 1998 to 2003), there were two antagonistic groups of supporters: "Protagonists for the pragmatic efficacy side" and "Protagonists for the procedural justice side" (Garcea, 2006: 215). The protagonists for the procedural justice side "suggested that those bills were not only unpalatable because they created two categories of Canadian citizens, but that they were also unconstitutional because they did not afford all citizens equal rights and protections under the Charter of Rights and Freedoms" (Garcea, 206: 215).

Citizenship '87' plan to change Canadian citizenship regime became effective through the enactment of (Bill) C-24, the Strengthening Canadian Citizenship. Scholars, lawyers, politicians and media criticized only the fact that C-24 created two categories of citizens and forgot that Bill C-24 does not only mean the "erosion of citizenship" (Kivisto \& Faist, 2007: 3) but above all the radical change of the regime of that citizenship. Under this new regime of citizenship, Canadian 
Citizenship became de facto a privilege for dual citizens. The privilege that was known to be characteristic of the fact for a foreigner to be allowed to immigrate to Canada - see the excerpt of the 1947 of then-1947, then-prime minister William Lyon Mackenzie King ${ }^{6}$-, however, gained ground from decade to decade to become the common denominator of everything that newcomers can achieve or acquire, including citizenship.

In 2014, i.e. 67 years after the above mentioned famous speech of Mackenzie King delivered in 1947, in the aftermath of the introduction of Bill C-24 in the House of Commons, Chris Alexander, the former minister of Citizenship and Immigration Canada, delivered a speech that seems to mean to immigrants that their integration is only an illusion. On February 6, 2014, at Fort York, Toronto, Ontario, minister Alexander in a rather nationalistic discourse recalled first the battle Canadians fought against Americans in 1812, then grounded reforms to the Citizenship Act in that historical context and finally redefined/reformulated the citizenship that new Canadians gain. Here is an excerpt from what he said:

Indeed, it is in honor of those who protected this city, in honor of those who have served and serve today, in honor of all who have made the sacrifice of war, and those who have contributed in their own way to building this great country, that we are further strengthening the value of Canadian citizenship. In recent years, our Government has implemented significant changes to Canada's generous immigration system. We have introduced a series of reforms to ensure that as we welcome newcomers to our country, we are meeting our economic and labour market needs. [...] We want newcomers to continue

\footnotetext{
${ }^{6}$ In 1947, then-prime minister William Lyon Mackenzie King said: "I wish to make it clear that Canada is perfectly within her rights in selecting the persons whom we regard as desirable future citizens. It is not a 'fundamental human right' of any alien to enter Canada. It is a privilege. It is a matter of domestic policy... The people of Canada do not wish, as a result of mass immigration, to make a fundamental alteration in the character of our population..." (Kelley and Trebilcock, 2003: 317. I highlight).
} 
down the path towards Canadian citizenship. We want new citizens to embrace our rich culture and values, and feel compelled to remain active members of Canadian society. Canadian citizenship is uniquely valuable in the world - it is a weighty privilege, that carries with it duties and rights, privileges and responsibilities. As we reform the immigration system, it's also critical to ensure that we protect and strengthen the great value of Canadian citizenship, and remind individuals that citizenship is not a right... it's a privilege. (Canada, 2014. I highlight.)

Redefining Canadian citizenship, making it a privilege instead of a right, results solely from changing the regime of that Canadian citizenship. That is what then-Minister Alexander goes on highlighting as follows in the same speech: "That's why, this morning, our Government tabled Bill C-24, the Strengthening Canadian Citizenship Act, in the House of Commons. By tabling this Act, we are meeting our commitment - in the most recent Speech from the Throne - to strengthen and protect the integrity of Canadian citizenship by introducing the first comprehensive reforms to the Citizenship Act in over a generation" (Ibid.). He specifies that "Not since 1977 - more than 36 years - have Canadians seen such significant changes to the Act, and as a government, we are confident that these changes reflect what Canadians want and expect: A system that emphasizes how great of a privilege Canadian citizenship is, while protecting it from abuse.” (ibid.)

As Macklin puts it, "A privilege in law belongs not to the recipient, but to the patron who bestows it. A right belongs to the one who bears it. When members of the executive declare that citizenship is a privilege and not a right, what they are asserting is their own power to take it away" (2014: 53). In other words, under C-24 and the then-Canadian citizenship regime it had created, citizenship for recent naturalized and dual Canadian citizens was not - to borrow from Hannah Arendt - a "right to have rights". Rather than being "a status of equality between members of a 
political community" (MacMahon, 2012:1), Canadian citizenship had become a hierarchized citizenship serving clearly and explicitly as a distinctive sign between true Canadians and immigrants (Bauder 2008). Yet C-24 did not specify whether it has at the same time changed the meaning of naturalization for new immigrants. According to Bridget Anderson, "Naturalization is when migrants become citizens, the moment when the Migrant, no longer solely an 'economic migrant', an 'asylum seeker', a 'dependent', becomes integrated, a fully incorporated member of the national community" (2013: 93). Particularly, "It is naturalization that enables what citizenship policy describes as 'full participation' through engagement in political, economic, and social relations" (Ibid.).

Before I close this chapter, I would be remiss if I did not quote Amanda Gallo's ideas developed in undergraduate honours thesis entitled "'Class-ifying' Canadian Citizenship": this is one of the few and rare apologetic academic works on (Bill) C-24, the Strengthening Canadian Citizenship Act. Part of the conclusion to her thesis is the following extensive paragraph:

What has, and continues to remain central to the conceptualization throughout the history of Canadian citizenship and immigration legislation is the desire to build a nation based on objectively-defined subjective characteristics of that which constitutes the "ideal Canadian." Just as Canadian immigration policy has explicitly legislated preferences of immigrants and prospective Canadians on the basis of race, so too does the SCCA [i.e. Strengthening Canadian Citizenship Act] explicitly legislate preferences for Canadianborn citizens without any citizenship ties to other nations. Legislation based upon an arbitrary definition of the ideal Canadian, however offensive to the sensibilities of Canadians and the liberal political ideologies contained in such legislation as the Charter or the Constitution has yet to prove contradictory with previous legislation which resulted 
in similar, if not explicitly similar, implications. Therefore, unless it can be established that Canadian citizenship legislation must be legislated in such a way as to provide citizens with equal individual rights and opportunities to express their citizenship and the rights/privileges it entails, as would be required in the liberal framework of citizenship, it seems unlikely that the SCCA would be found contrary to existing conceptualizations of citizenship in legislation. This is because the SCCA, with its intention to strengthen Canadian citizenship and privilege those citizens who, by virtue of such traits as their decision to possess citizenship status in Canada alone, fits historical trends of citizenship and immigration legislation. Moreover, even if such a legislative requirement were to be implemented, legislating citizenship under such an assumption, wherein all citizens are treated as equal individuals with equal opportunities to express and practise their citizenship, effectively denies those groups of citizens the systemic disadvantages they experience in the expression of their citizenship because of the embedded hierarchies of privilege that have existed throughout the course of Canadian history. In essence, the classification of Canadian citizens would most likely remain, although in a more implicit manner; akin to the conceptualization and practise of Canadian citizenship prior to the introduction of the SCCA. In a somewhat anticlimactic turn of events, therefore, the implementation of the SCCA, in terms of its capacity to create classes of citizenship, is little more than an explicit retelling of the immigration and citizenship legislation which preceded it. (2016: 39-40. Italics are mine)

According to the author, C-24 is consistent with all Canadian immigration policies which are deemed to be racist and discriminatory. However, the author, while showing herself as an ardent defender of Canadian citizenship resulting from C-24, which she presents as perfectly fitting with 
the republican tradition of citizenship and as rhyming with the discriminatory policies of immigration we already know, she totally neglects the 1977 Citizenship Act, which C-24 seeks to replace. Moreover, Gallo does not mention whether the 1977 Act was inspired by the Republican Concept or not, or whether it too openly asserted the supremacy of one group of citizens on the rest of all Canadian citizens. Furthermore, the author makes no reference to the Multiculturalism policy that Canada has adopted since 1971. According to then-prime minister Pierre Trudeau, Multiculturalism Policy means that in Canada "there is no official culture, nor does any ethnic group take precedence over any other. No citizen or group of citizens is other than Canadian, and all should be treated fairly" (cited in Siemiatycki, 2015: 103). It would be absolutely absurd to continue conceiving and making not only immigration policies and laws but above all Canadian citizenship regime in terms of the so-called "ideal Canadians", while the country welcomes no less than three hundred thousand of immigrants each year.

In concluding this chapter, I would say that while there are discriminatory immigration policies and laws, there are others that have been designed to allow immigrants to integrate into the Canadian society. But as we have demonstrated so far, above all, it is the Canadian citizenship status that crowns a successful integration; however its legal acquisition must also be accompanied by favorable conditions enabling new citizens to participate actively and without hindrance in the socio-economic and political life of the country. As Anderson expresses it well, "Obtaining Canadian citizenship is generally a momentous occasion for immigrants and refugees. [...] As citizens, the foreign-born acquire important political rights that they were previously denied" (Anderson, 2008: 82). 


\section{Chap.3. C-6: The fall of C-24 and the Return to the 1977 Canadian Citizenship Regime}

On February $25^{\text {th }}, 2016$, the former Minister of Immigration, Refugee and Citizenship, the Honourable John McCallum introduced in the House of Commons Bill C-6, An Act to amend the Citizenship Act and make consequential amendments to another Act. "This bill makes changes to the legislative provisions regarding grants of citizenship by naturalization, grounds for revoking citizenship, and the Minister's authority with regard to fraudulent documents" (Béchard and Elgersma, 2016: 1). On June 19, 2017 Bill C-6 received the royal assent and became a law. Commenting on Bill C-6 promulgation, the current Minister of Immigration, Refugee and Citizenship, the Honourable Ahmed Hussen said: “Canada's identity has always been shaped by the significant economic, cultural and social contributions of immigrants. Changes to the Citizenship Act will enhance program integrity, while giving more flexibility to eligible applicants to meet the requirements for citizenship so that they can continue building successful lives in Canada" (Canada, 2017). Comments that constitute a turn away from the former Conservative Minister Jason Kenny' expression of Bill C-24 main purpose: making Canadian citizenship "harder to get and easier to lose" for recent naturalized Canadians. In this chapter, I intent to look at Bill C-6 enactment as less than a new Canadian citizenship regime change and more like a return to Canadian citizenship regime that was in effect prior to the advent of Bill C-24, the Strengthening Canadian Citizenship Act. As I put it earlier, both the fall of C-24 and the ascent of (Bill) C-6 are likely to be well analyzed if they are placed in the political environment of that time, that is, the 2015 federal election campaign. At this point, it is worth recalling the key driver question of my study, that is: "Strengthening Canadian citizenship: but how and for whose benefit?" This time, it is also important to ask this other question: "Who are the Canadians who benefit or lose from C24 , and who are the beneficiaries or losers of C-6? 
The first of the four dimensions of a citizenship regime discussed by Jane Jenson and Martin Papillon (2000) is about establishment of "boundaries of inclusion and exclusion" of a given political community. According to Jenson and Papillon, precisely, "through formal recognition of particular rights (civic, political, social, cultural, as well as individual and collective) and access to mechanisms for the exercise of those rights, a citizenship regime establishes the boundaries of inclusion and exclusion of a political community. In doing so, it identifies those entitled to full citizenship status and those who only, in effect, hold second-class status" (2000: 246). Provisions of C-24 regarding citizenship revocation for dual Canadian citizens convicted of committing serious crimes as well as the requirement for recent naturalized Canadians to continue residing inside Canada once guaranteed citizenship, those two clauses alone are enough to help us identify who are deemed to be full Canadian citizens and those who are second-class Canadian citizens under the citizenship regime that was established by Harper's government. Clearly, the new Conservative citizenship regime was intended to distinguish, to borrow from Gallo (2016) the "ideal Canadians" i. e. the "insiders"- single- nationals from recent and dual-nationals, the "outsiders". To cite Gallo, "Just as Canadian immigration policy has explicitly legislated preferences of immigrants and prospective Canadians on the basis of race, so too does the SCCA [i.e. Strengthening Canadian Citizenship Act] explicitly legislate preferences for Canadian-born citizens without any citizenship ties to other nations" (2016: 39). An excerpt that in some way answers the question of who are the beneficiaries and losers of Bill C-24. A law that worked in favor of ideal Canadians to the detriment of other Canadians likely to have dual nationality.

The discussion about distinguishing "ideal-Canadians-insiders" from "Others-outsiders", a distinction that is reflected in C-24, calls for a reflection on Conservatives' politics of division which was conveyed by, and reflected in, the Harper's expression "new and existing and old-stock 
Canadians". As mentioned earlier, the former Conservative Prime Minister used such a language to categorize Canadians during the 2015 federal election campaign in which immigration, refugee as well as "citizenship issues were prominent", and when the debate on how the new citizenship law created two categories of Canadian citizens was bitter. It is important to point out that the fact of associating debate on citizenship and federal election campaign is not a mere coincidence. In fact, according to Kernerman and Resnick, "the electoral system, [institutions of Canadian] federalism, and the Charter of Rights and Freedoms" are considered to be the "three key citizenshaping institutions" (2005:3). As the president of EKOS Research Frank Graves puts it, "Harper's use of the term 'old-stock Canadians' in [a federal election campaign] debate was a deliberate ploy to energize his supporters, part of the overall strategy to create a sense of us-versusthem" (in Gollom 2015). But to send back-to-back the so-called old-stock Canadians and recent Canadians/immigrants is to play a dangerous game that undermines the Canadian citizenry cohesion at different levels. Put back in their political context and environment, C-24 and thenPrime Minister's language consolidate to tear apart empathy that citizens of each nation should normally manifest among themselves. According to Alan Cairns, such an empathy plays a keyrole in unifying not only citizens of a nation-state but especially in connecting citizens "with each other via empathetic relationship"; "it is this empathetic community that transcends national differences to create common citizenship" (in Green, 2005: 228). To give an example of negative impacts Harper's harmful language has had on racialized Canadians, one can cite former Quebec Liberal MP Marlene Jennings' grievance”. According to CBC News, Jennings "took offence to Harper's use of the phrase in the debate". Commenting on that phrase, she specified: “All my life that word has been used to say I'm not a real Canadian. [...] It's used against people

\footnotetext{
${ }^{7}$ Marlene Jennings was "the first black woman from Quebec to be elected to Parliament" (CBC News, 2015).
} 
who don't quite look like what some people think Canadians should look like" (cited in CBC News 2015).

Nevertheless, both connections among citizens as well as the ways in which citizens are connected to the state, are governed and dominated by different policies put in place by the state for that specific purpose; but above all, Citizenship policy plays a pivotal role in such matters. By enacting Bill C-24, the Conservative government was detached from its "commitment to the fundamental principles of equality, diversity, and community as the basis of Canada's free, bilingual, multicultural society" (Canada, 1987: 8). By introducing a citizenship regime that straddles and ranks Canadians, the Conservative government failed to fulfill its "primary" and "related tasks" whose ultimate goal is bringing together all Canadian citizens in a multicultural Canada. According to Cairns, "[t]he primary tasks of the state are the creation and maintenance of internal order and the protection of its own territorial integrity... A related task is the integration of the regions, classes, ethnicities, and other cleavages that always threaten to pull society apart, erode the sense of community and weaken the capacity for collective action" (in Hanvelt and Papillon, 2005: 242). The federal election campaign became an opportunity for Liberals to express their opposition to Conservative divisive politics and practice which was this time enshrined in the Citizenship Act. Hence, it could be said that the Conservatives' electoral defeat precipitated the fall of Bill C-24, which was recently replaced by Bill C-6.

On the Web site of the Parliament of Canada, House of Commons the summary of Bill C6 - assented on June 19, 2017 - reads as follows:

This enactment amends the Citizenship Act to, among other things, 
(a) remove the grounds for the revocation of Canadian citizenship that relate to national security; (b) remove the requirement that an applicant intend, if granted citizenship, to continue to reside in Canada; (c) reduce the number of days during which a person must have been physically present in Canada before applying for citizenship and provide that, in the calculation of the length of physical presence, the number of days during which the person was physically present in Canada before becoming a permanent resident may be taken into account; (d) limit the requirement to demonstrate knowledge of Canada and of one of its official languages to applicants between the ages of 18 and 54; (e) authorize the Minister to seize any document that he or she has reasonable grounds to believe was fraudulently or improperly obtained or used or could be fraudulently or improperly used; (f) change the process for the revocation of Canadian citizenship on the grounds of false representation, fraud or knowingly concealing material circumstances; and (g) remove the requirement that an applicant be 18 years of age or over for citizenship to be granted under subsection 5(1) of that Act.

It also makes consequential amendments to the Immigration and Refugee Protection Act. ${ }^{8}$

Far from being a new conceptualization of Canadian citizenship, C-6 as it is summarized above reverts C-24 and largely restores the citizenship regime of 1977. The concept of "ideal Canadian" that shapes and fuels C-24, a concept that serves to define "genuine or true Canadians", and to distinguish deserving Canadians from undeserving ones, has been replaced by Trudeau's expression "A Canadian is a Canadian is a Canadian" that seeks to affirm the "inviolability" of Canadian citizenship status and disapprove a conditional Canadian citizenship that was established

\footnotetext{
${ }^{8}$ Retrieved from: http://www.parl.ca/DocumentViewer/en/42-1/bill/C-6/royal-assent
} 
by $\mathrm{C}-24$. It is also important to underline the real function of naturalization and its place in citizenship legislation: simply, naturalization transfigures "outsiders-foreigners" into "insiderscitizens", firmly. On the relationship between Naturalization and Citizenship, Bridget Anderson notes that "Naturalization is the process through which individuals can become citizens, given the same status as those who are 'natural-born' citizens (or subjects), hence the term. In this way citizenship is a unitary status with no distinction between the natural-born and the naturalized" (2015: 30).

Now that C-24 has been repealed by C- 6 which reaffirms "that Canadian citizens by birth and citizens by choice have identical rights and responsibilities" (Canada, 1987: 8), there is no reason for one to wonder who are the beneficiaries and losers of recent Canadian citizenship regime change. New Canadians whose citizenship was eroded by C-24 have for sure welcomed the enactment of Bill C-6. Nevertheless, all Canadian should be proud of a citizenship legislation that binds them together not only for their own good but also for the good of future generations. 


\section{Conclusion: Canadian citizenship and New Canadians' Alientity}

In an article revisiting his long academic career, Alain Cairns states that "one of the tasks of social science" is to propose "new labels for emerging realities that do not fit comfortably into our existing vocabulary" (2005: 344). "A new label”, Cairns contends, "gives a new meaning, or a modified meaning, to whatever we are trying to make sense of, a meaning that would not be communicated effectively by label from the past" (Ibid.). Recent changes to the Canadian citizenship regime that have redefined profoundly how dual Canadian citizens and recent immigrants relate to Canada as a nation-state, would be part of those "emerging realities". Thus, a new label that can allow to convey their exact meaning and grapple with their consequences is vehemently needed. Such a label would also help us to determine - to borrow to Bridget Anderson - "the contingency of citizenship" (2013:93) bestowed to those who will always be the "Outsiders". Therefore, in this conclusion, I will argue that recent changes to Canadian citizenship regime that aimed at making Canadian citizenship a reflection of ideal Canadians exclude new Canadians from "mainstream 'Canadian identity"' (Arat-Koc, 2006: 227) and confine them to living in state of alienhood; thus, their alientity is coined and defined as opposed to the above-mainstream Canadian identity.

But what is alientity? According to Bernard Lamizet, "Alientity' is a term coined in opposition to 'identity'. Whereas identities are the object of representations that are expressed in the course of symbolic exchanges, discourses and communication, 'alientity' refers to what cannot be the object of representations, what is outside the public sphere and outside the ordinary spheres of language and symbolic practice" (Lamizet, 2014). More importantly, alientity, as it is for identity, is defined and recognized as such by the dominant. Lamizet argues that "Basically, Alien is the English term for what can be called an unalterable alterity. [...] Thus, alientity is, in the first 
place, part of public space as a manifestation of the closure of the political dimension of identity"9(Lamizet, 2015: 11,13. I translate.). Thus, in both identity and alientity is embedded a political dimension since both are intertwined with the dominant power which assign to each of them its place and meaning. As Lamizet puts it, "In the field of political logic of identity, the relation to alientity manifests itself, thus, in a certain relation to power based on several expressions. The dominant first expresses its relation to alientity in the definition of identity and in the fixing of the criteria which recognize it by distinguishing it from alientity, instituted in the same way by the dominant"10 (2015: 95. I translate.).

Thus, as a supreme regulating agency, the government intervenes to control the functioning of both identity and alientity: "Whether it be national identity, professional identity or cultural forms of identity, the dominant establishes the relationship to alientity by setting standards that impose a form of recognition"11 (Ibid. I translate.). More importantly, the author notes, "Alientity is thus subjected to the dominant force which implements strategies to reduce it and to force those who are subjected to it to acquire the dominant identity and to reject the forms of alientity which they could carry"12 (2015: 95. I translate.). The concept of alientity as it is developed by Lamizet can be used to describe the place reserved to "visible minorities" in Canada. That concept can also be completed by Marciniak's concepts “alienness" or "Immigrants' state of alienhood" in the U.S.

\footnotetext{
9 "Signifiant, fondamentalement, "étranger", Alien est le terme anglais qui désigne ce que l'on peut appeler une inaltérable altérité. [...] L'alientité s'inscrit, ainsi, d'abord, dans l'espace public comme une manifestation de la cloture de la dimention politique de l'identité" (Lamizet, 2015: 11\&13).

${ }^{10}$ Le pouvoir exprime, d'abord, sa relation à l'alientité dans la définition de l'identité et dans la fixation des critères qui la reconnaissent en la distinguant de l'alientité, instituée de la même façon par le pouvour. (Lamizet, 2015: 95).

11 "Qu'il s'agisse de l'identité nationale, de l'identité professionnelle ou des formes culturelles de l'identité, le pouvoir institue la relation à l'alientité en fixant des normes qui imposent une forme de reconnaissance" (Ibid.).

12 "L'alientité est ainsi soumise au pouvoir qui met en oeuvre des stratégies destinées à la réduire et à contraindre ceux qui lui sont soumis à acquérir l'identité dominante et à rejeter les formes d'alientité dont ils pouvaient être porteurs" (Lamizet, 2015: 95).
} 
In her article entitled "Immigrant Rage: Alienhood, 'Hygienic' Identities, and the Second World" where she reflects on the fate of immigrants in the USA, Katarzyna Marciniak presents "alienhood" as "a legally sanctioned discursive and disciplinary apparatus that classifies immigrants, refugees, and border crossers in relation to U.S. territory. This relation is one of tenuous belonging and positions 'legal aliens' in specific ways" (2006: 34). As for "alienness", the author presents it as "an inevitable marker of difference" (2006: 44) used stereotypically to designate "people of color" as well as "the poor, those whose faiths dictate particular clothing, or those who speak English with an accent" (Ibid.). The author notes that all those categories are "vulnerable to charges of alienhood" (Ibid.), a term she goes on conceptualizing as "a historically burdensome difference in relation to the 'legitimate' American citizen" (2006: 34). The situation prevailing in the United States of America is not different from what happens to recent new Canadians and recent immigrants in Canada.

Foreign-born Canadians as well as recent immigrants experience the same systemic racism and discrimination, in addition to the mirages of naturalization mentioned earlier. Principally, due to the unstable Canadian citizenship regime, legal citizenship and substantial citizenship of new Canadians are also unstable and subject to change whenever citizenship policy or immigration legislation change. And the more their citizenship status is weakened, the more their foreignness rises to the surface. In Canada, especially, researchers and politicians have created appropriate terms to designate those naturalized Canadians whose foreignness dominates their Canadianness. The use of the term "Visible minority"- i.e. "persons, other than Aboriginal persons, who are nonCaucasian in race or non-white in colour" (Statistics Canada, 2013: 14) - is a good example to express accurately the alientity of those who can become Canadians via naturalization but who cannot be part of mainstream Canadian identity. According to Arat-Koc, in the aftermath of 9/11 
terrorist attacks, the latter is understood as "redefinition and reconfiguration of Canadian identity as denoting one's belonging in the 'West'” (Arat-Koc, 2006: 227), which excludes automatically visible minorities. By officially designating non-ideal Canadians by terms such as racialized people or visible minority, the dominant group defines their alientity and sends a clear message to them that - to borrow from Winter - Canada "is not [their] country" (2015: 28). To paraphrase Mohanty ${ }^{13}$, in Canada, immigrants can become naturalized Canadians but they will always be nonideal Canadians. A status quo that unfortunately Bill C-6 enactment cannot change.

${ }^{13}$ Speaking of immigrants' situation in the U. S., Mohanty states: "One can be either a resident or illegal immigrant, but one is always an alien. There is no confusion here [...]: one's status as an 'alien' is primary" (1998: 492). 


\section{References}

Anderson, Bridget. "Us and Them? Social justice, citizenship, and migration." In Judith Gruber, and Sigrid Rettenbacher. Migration as a sign of the times: Towards a theology of migration. Leiden: Brill Rodopi, 2015.

Anderson, Bridget. Us and Them? The dangerous politics of immigration control. Oxford: Oxford University Press, 2013.

Anderson, Christopher G. "A Long-Standing Canadian Tradition: Citizenship Revocation and Second-Class Citizenship Under the Liberals, 1993-2006." Journal of Canadian Studies/Revue d'études canadiennes 42.3 (2008): 80-105.

Anderson, Christopher G. Rethinking Equality: The Challenge of Equal Citizenship. Manchester University Press, 2006.

Anderson, Christopher G. "Immigration, Immigrants, and the Rights of Canadian Citizens in Historical Perspective." International Journal of Canadian Studies 43 (2011): 207-219.

Anderson, Christopher G. Canadian Liberalism and the Politics of Border Control, 1867-1967. Vancouver, Toronto: UBC Press, 2013.

Anderson, Christopher G. "Immigration, Immigrants, and the Rights of Canadian Citizens in Historical Perspective". Miscellaneous: International Perspectives on Canada 43 (2011): 207-219. Retrieved from: https://www.erudit.org/en/journals/ijcs/2011-n43ijcs0122/1009461ar.pdf 
Anderson, Christopher G. and Black, Jerome H. "The Political Integration of Newcomers, Minorities, and the Canadian-Born: Perspectives of Naturalization, Participation, and Representation. In John Biles, Meyer Burstein, and James Frideres (Eds.). Immigration and Integration in Canada. Kingston: School of Policy Studies, Queen's University, 2008.

Arat-Koc, Sedef. "Whose transnationalism? Canada, 'Class of civilizations' discourse, and Arab and Muslim Canadians". In Lloyd L. Wong, and Vic Satzewich. Transnational Identities and Practices in Canada. Vancouver, Toronto: UBC Press, 2006.

Bauder, Harald. "Citizenship as Capital: The Distinction of Migrant Labor." Alternatives: Global, Local, Political 33. 3 (2008): 315-333.

Bauder, Harald, and Christian Matheis. Migration Policy and Practice: Interventions and Solutions. Palgrave Macmillan, 2016.

Béchard, Julie; Becklumb, Penny and Elgersma, Sandra. Bill C-24: An Act to amend the Citizenship Act and to make consequential amendments to other Acts. Retrieved from: http://www.lop.parl.gc.ca/content/lop/legislativesummaries/41/2/c24-e.pdf

Béchard, Julie and Elgersma, Sandra. Bill C-6: An Act to amend the Citizenship Act and to make consequential to another Act. Retrieved from: http://www.lop.parl.gc.ca/Content/LOP/LegislativeSummaries/42/1/c6-e.pdf 
Bekemans, Léonce. "Identity and Identity-building in Europe: A Citizenship Perspective”. In Bognár, Bulcsu, and Zsolt Almási. (Eds). Transfigurations of the European Identity. Newcastle upon Tyne, UK: Cambridge Scholars Publishing, 2014.

Bellamy, Richard. Rethinking Liberalism. London: Pinter, 2000.

Biles, John. "Integration policies in English-Speaking Canada". In John Biles, Meyer Burstein, and James Frideres (Eds). Immigration and Integration in Canada. Kingston: School of Policy Studies, Queen's University, 2008.

Bloemraad, Irene. "Citizenship and Pluralism: Multiculturalism in a World of Global Migration".

In Gökçe Yurdakul, and Y. M. Bodemann. Citizenship and Immigrant Incorporation: Comparative Perspectives on North America and Western Europe. New York: Palgrave Macmillan, 2007.

Bognár, Bulcsu, and Zsolt Almási. Transfigurations of the European Identity. Newcastle upon Tyne, UK: Cambridge Scholars Publishing, 2014.

Cairns, Alan C. "Introduction". In Cairns, Alan C. et al. Citizenship, Diversity, and Pluralism: Canadian and Comparative Perspectives. Montreal, Kingston: McGill-Queen's University Press, 1999.

Cairns, Alan C. "My academic career: The pleasures and risks of introspection." In Alan C. Cairns, Gerald P. Kernerman, and Philip Resnick. Insiders and Outsiders: Alan Cairns and the Reshaping of Canadian Citizenship. Vancouver, Toronto: UBC Press, 2005. 
Cairns, Alan C. et al. Citizenship, Diversity, and Pluralism: Canadian and Comparative Perspectives. Montreal, Kingston: McGill-Queen's University Press, 1999.

Cairns, Alan C., Gerald P. Kernerman, and Philip Resnick. Insiders and Outsiders: Alan Cairns and the Reshaping of Canadian Citizenship. Vancouver, Toronto: UBC Press, 2005.

Canada. Archived - Speaking notes for Chris Alexander, Canada's Citizenship and Immigration Minister at a News Conference to Announce the Tabling of Bill C-24: The Strengthening Canadian Citizenship Act. Last date modified: 2014-02-06. Retrieved from: https://www.canada.ca/en/news/archive/2014/02/speaking-notes-chris-alexander-canadacitizenship-immigration-minister-news-conference-announce-tabling-bill-c-24$\underline{\text { strengthening-canadian-citizenship-act.html }}$

Canada. Department of the Secretary of State of Canada. Citizenship '87: Proud to be Canadian: A Discussion Paper. Dept. of the Secretary of State of Canada, 1987.

Canada. Citizenship Bill [C-6] Receives Royal Assent.

Last date modified: 2017-06-19. Retrieved from: https://www.canada.ca/en/immigrationrefugees-citizenship/news/2017/06/citizenship_billreceivesroyalassent.html

Canadian Association of Refugee Lawyers (CARL). "Citizenship is not a licence the government can revoke for misbehavior". Challenging Misinformation: Canadian Citizenship Law Explained. Last updated: 2017. Retrieved from: http://www.carl-acaadr.ca/challengingmisinformation\#1.\%20Citizenship\%20is\%20not\%20a\%20licence\%20the\%20governmen t\%20can\%20revoke\%20for\%20misbehavior 
CBC News. Harper's 'old-stock Canadians' line is part deliberate strategy: pollster. Last Updated: Sep 18, 2015. Retrieved from: http://www.cbc.ca/news/canada/montreal/harper-old-stock$\underline{\text { canadians-debate- } 1.3233615}$

Dahlstedt, Magnus, Anders Neergaard, and Sara Ahlstedt. International Migration and Ethnic Relations: Critical Perspectives. vol. 148. Routledge, New York, New York; London, UK: 2015.

Dahlstedt, Magnus, Mikael Rundqvist and Viktor Vesterberg. "Rights, Obligations and changing citizenship ideals". In Magnus Dahlstedt, Anders Neergaard, and Sara Ahlstedt. International Migration and Ethnic Relations: Critical Perspectives. vol. 148. Routledge, New York, New York; London, [England]: 2015.

Frideres, James S., et al. Immigration and Integration in Canada in the Twenty-First Century. School of Policy Studies, Queen's University, 2008.

Gallo, Amanda. Class-ifying Canadian Citizenship. Unpublished Thesis for Honours Bachelor of Arts, Political Science, Pre-Law. Lakehead University, Thunder Bay Campus (May 2016). Retrieved from: https://www.researchgate.net/publication/313510758

Garcea, Joseph. "The Third Phase of the Canadian Citizenship Project: Reform Objectives and Obstacles". In Hans J. Michelmann, David E. Smith, and Cristine De Clercy. (Ed.) Continuity and Change in Canadian Politics: Essays in Honour of David E. Smith. Toronto: University of Toronto Press, 2006. 
Gollom, Mark. "Stephen Harper's 'old-stock Canadians': Politics of division or simple slip? Debate rages whether Tory leader's comment was 'dog whistle politics' or a chance remark." $C B C$ News. Retrieved from: http://www.cbc.ca/news/politics/old-stock-canadians-stephenharper-identity-politics-1.3234386

Hanvelt, Marc and Papillon, Martin. "Parallel or Embedded? Aboriginal self-government and the changing nature of citizenship in Canada". In Cairns, Alan C., Gerald P. Kernerman, and Philip Resnick. (Eds.). Insiders and Outsiders: Alan Cairns and the Reshaping of Canadian Citizenship. Vancouver, Toronto: UBC Press, 2005.

Heater, Derek Benjamin. What is Citizenship? Cambridge: Polity Press, 1999.

Honohan, Iseult. Liberal and republican conceptions of citizenship. In Ayelet Shachar, Rainer Bauböck, Irene Bloemraad and Maarten Vink. (Eds.). Oxford Handbook of Citizenship. Oxford University Press, 2017. Retrieved from:

https://www.researchgate.net/publication/310800275_Liberal_and_republican_conceptio ns_of_citizenship

Innes, Alexandria. Migration, Citizenship and the Challenge for Security: An Ethnographic Approach. Palgrave Macmillan, 2015.

Isin, Engin F., and Patricia K. Wood. Citizenship and Identity. London (UK), Thousand Oaks (Ca): Sage, 1999.

Janoski, Thomas. Citizenship and civil society: A framework of rights and obligations in liberal, traditional, and social democratic regime. Cambridge: Cambridge University Press, 1998. 
Jenson, Jane, and Susan D. Phillips. 2001. "Redesigning the Canadian Citizenship Regime:

Remaking the Institutions of Representation.” In Colin Crouch, Klau Eder, and Damian Tambini. (Eds.). Citizenship, Markets, and the State. Oxford: Oxford University Press, 2001.

Jenson, Jane, and Martin Papillon. "Challenging the Citizenship Regime: The James Bay Cree and Transnational Action." Politics \& Society 28. 2 (2000): 245-264.

Kaplan, William. Belonging: The Meaning and Future of Canadian Citizenship. McGill-Queen's University Press, 1993.

Kelley, Ninette; Trebilcock, Michael J. The Making of the Mosaic: A History of Canadian Immigration Policy. Toronto: University of Toronto Press, 2013.

Kernerman, Gerald P. and Resnick, Philip. "Introduction”. In Cairns, Alan C., Gerald P. Kernerman, and Philip Resnick. (Eds.). Insiders and Outsiders: Alan Cairns and the Reshaping of Canadian Citizenship. Vancouver, Toronto: UBC Press, 2005.

Kivisto, Peter, and Thomas Faist. Citizenship: Discourse, Theory, and Transnational Prospects. Blackwell Pub, 2007.

Knowles, Valerie. Strangers at our Gates: Canadian Immigration and Immigration Policy, 15402015. (4th Edition). Toronto: Dundurn, 2016.

Kymlicka, Will, and W. J. Norman. Citizenship in Diverse Societies. Oxford University Press, 2000. 
Lamizet, Bernard. "Alientité et Communication." Hermès 68. 1 (2014): 195. Retrieved from: http://documents.irevues.inist.fr/handle/2042/58417

Lamizet, Bernard. L'alientité. Paris: Mimesis, 2015.

Landes, Ronald G. The Canadian Polity: A Comparative Introduction. Prentice-Hall Canada, 1991.

MacMahon, Simon. "Introduction: Developments in the theory and practice of citizenship". In Simon McMahon (Ed.). Developments in the theory and practice of citizenship. Newcastle upon Tyne: Cambridge Scholars Publishing, 2012.

Marciniak, Katarzyna. Alienhood: Citizenship, Exile, and the Logic of Difference. University of Minnesota Press, 2006.

Marciniak, K. "Immigrant Rage: Alienhood, "Hygienic" Identities, and the Second World." Differences 17. 2 (2006): 33-63.

Marshall, Thomas Humphrey. Citizenship and Social Class. Cambridge: Cambridge University Press, 1950.

Merry, Michael S. Equality, Citizenship, and Segregation: A Defense of Separation. Palgrave Macmillan, 2013.

Michelmann, Hans J., David E. Smith, and Cristine De Clercy. Continuity and Change in Canadian Politics: Essays in Honour of David E. Smith. University of Toronto Press, 2006. 
Mohanty, Chandra Talpade. "Crafting Feminist Genealogies: On the Geography and Politics of Home, Nation, and Community.” In Ella Shohat. Talking Visions: Multicultural Feminism in a Transnational Age. Cambridge: MIT P, 1998.

Mulhern, J.J. "The political economy of citizenship: A Classical Perspective.” In in Jose V. Ciprut (Ed.). The Future of Citizenship. Cambridge, Mass: The MIT Press, 2008.

Ray, B. N. Citizenship in a globalizing World. New Delhi: Kaveri Books, 2007.

Said, Edward W. Culture and imperialism. New York: Knopf, 1993.

Shields, John, et al. Immigrant Settlement and Integration Services and the Role of Nonprofit

Service Providers: A Cross-National Perspective on Trends, Issues and Evidence 2016/1. Toronto, Ontario: Ryerson Centre for Immigration and Settlement, 2016.

Siemiatycki, Myer. "Continuity and change in Canadian immigration policy." In Harald Bauder and John Shields (Eds.). Immigrant Experiences in North America. Understanding Settlement and Integration. Toronto: Canadian Scholars' Press, 2015.

Statistics Canada. Immigration and Ethnocultural Diversity in Canada. Ottawa: Government of Canada, 2013.

Statistics Canada. Population growth in Canada: From 1851 to 2061. Population and dwelling counts, 2011 Census. Census in Brief. Ottawa: Government of Canada, 2012. Retrieved from: http://www12.statcan.gc.ca/census-recensement/2011/as-sa/98-310-x/98-310x2011003_1-eng.pdf 
Steenbergen, Bart V. The Condition of Citizenship. Sage, 1994.

Winter, Elke, and Institute for Research on Public Policy (IRPP). "Becoming Canadian: Making Sense of Recent Changes to Citizenship Rules”. IRPP Study, 44 (2014).

Young, Margaret, and Canada. Parliamentary Research Branch. Canadian Citizenship Act and Current Issues. BP-445E, Parliamentary Research Branch, 1997. Retrieved from: https://lop.parl.ca/Content/LOP/ResearchPublicationsArchive/pdf/bp1000/bp445-e.pdf 